\title{
Bank Risk Determinants in Latin America
}

\author{
Mariña Martínez-Malvar ${ }^{1}\left(\mathbb{D}\right.$ and Laura Baselga-Pascual ${ }^{2, *}$ \\ 1 Department of Counterparty Credit Risk (CCR), Nordea Bank Danmark, Grønjordsvej 10, 2300 Copenhagen, \\ Denmark; Marina.martinez.malvar@nordea.com \\ 2 Department of Finance and Accounting, Deusto Business School, University of Deusto, Mundaiz Kalea, 50, \\ 20012 Donostia, Spain \\ * Correspondence: lbaselga@deusto.es
}

Received: 1 August 2020; Accepted: 1 September 2020; Published: 7 September 2020

\begin{abstract}
Systemic Banking crises are a recurrent phenomenon that affects society, and there is a need for a better understanding of the risk factors to support prudential regulation and reduce unnecessary risk intake in the financial system. This paper examines the main bank risk determinants in Latin America. The period analysed covers the timespan from 1999 to 2013, including the systemic banking crisis episodes in Argentina (2001-2003) and Uruguay (2002-2005). We apply a new data-driven comparable methodology to classify and select commercial banks from the sample. We study bank risk proxied by the Z-score. We use the system-GMM estimator as our main empirical analysis method. According to our results, well capitalized, liquid, and traditional commercial banks are less risky. We perform robustness tests by applying OLS, and the results resemble our original model.
\end{abstract}

Keywords: Latin America; financial risk and risk management; banks and depository institutions; bank risk management; emerging markets

JEL Classification: G21; G32; L11

\section{Introduction}

Banking crises and banking regulation are recurrent topics in the economic policy debate. Since the early seventies, banking crises have frequently affected developing and transitioning economies to a greater extent than others (Caprio and Klingebiel 1997). Nonetheless, there is a lack of understanding of the factors that generate banking crises. Regulators tend to assist, more than to resolve the causes of, insolvent institutions (Kane 2016). Prudential regulation aims to reduce excessive bank risk-taking and capital shortages in an attempt to protect society (Kane 2016). Unfortunately, these controls tend to arrive too late, after a crisis is already spreading. Therefore, a better understanding of the risk factors could be helpful in further reducing risk, mainly when regulators' powers enable authorities to address situations of distress before they spread to the wider financial system (Schich and Byoung-Hwan 2010).

In this paper, we study the determinants of bank risk in Latin America. Although several studies have focused on bank risk determinants such as capitalization, asset and management quality, profitability, and liquidity (Araújo and Leao 2013; Altunbas et al. 2007; Eichengreen and Rose 1998; Goldstein et al. 2000; Aldasoro Iñaki and Drehmann 2018; Mäkinen and Solanko 2017), their results are inconclusive, which implies the need for further research. Moreover, we focus on the Latin American banking sector, the particularities of which create an interesting case study. Rojas-Suárez and Weisbrod (1996) show that banking crises in Latin America are different from those in the developed world. For instance, Latin American markets are highly concentrated, and possess significant barriers of entry that might increase the risk of financial distress (Enoch et al. 2016). In highly concentrated banking systems, the collapse of a banking institution can cause distress in the entire financial system. The five largest banks in South America hold three-quarters of the total banking assets of the region (BIS 2007). 
Agnoli and Vilán (2008) show that banking systems in Latin America have higher concentrations and market power than European and Asian banking systems. Another key issue is the way banking crises are managed; Laeven and Valencia (2012) showed that banking crises in developed countries tend to apply macroeconomic policies, while the bank restructuring approach ${ }^{1}$ is more popular in developing countries. An additional peculiarity of Latin American economies is inflation and hyperinflation, which influences the banking sector, financial leverage, and financing sources. Latin American banks have experienced distress after the stabilization of inflation. Financial intermediaries profit from float of payments in scenarios of chronic high inflation, meaning that when the inflation is reduced, a source of income disappears (Demirgüç-Kunt and Detragiache 1998). Finally, Latin America has a special pressure from rising interest rates due to financial risks and market volatility (Enoch et al. 2016). Additionally, risks persist in the form of possible changes in US policies, principally those towards greater trade protectionism or those that increase the risk aversion of investors, which is a consequence of the tighter financial conditions of international markets (Banco de España 2017).

This paper contributes to the literature on three main aspects. First, we analyse the microeconomic factors of the Latin American banking crises. This work complements previous literature by analysing the main bank-specific risk determinants, controlling for macroeconomic and regulatory variables. Banking crises in Latin America have mainly been analysed from a macroeconomic perspective, focusing on the risk intake due to the foreign capital inflows, the impact of foreign institutions, currency crises, or sovereign debt crises (Enoch et al. 2016; García-Herrero 1997; Galindo et al. 2010). However, little research has been conducted on the effects of bank-specific variables on the risk of Latin American banks, with the exception of Rojas-Suarez (2001), and Pellegrini et al. (2019). Additionally, Latin American financial systems exhibit differences that make it impossible to extend the conclusions from other regions' analyses. Second, we add clarity to the impact of different indicators on the risk of financial institutions. Even though there is agreement on the identification of banking risk factors, there is an open discussion on the direction of the impact. Finally, we use the generalized method of moments (GMM) estimator developed for dynamic panel models by Arellano and Bover (1995) and Blundell and Bond (1998). This allows us to control for unobserved heterogeneity, as well as for endogeneity. This technique has not been applied on the analysis of the Latin American banking system. Additionally, we apply a recently defined analysis to classify commercial banks across the region.

Our results show a negative relationship between the capitalization, asset quality and liquidity of a bank and its risk, suggesting that well capitalized, liquid, and traditional commercial banks tend to be less risky. Our results are of interest for regulators and policy makers in scenarios of uncertainty and expected economic recession due to the COVID-19 pandemic.

The remainder of the paper is structured as follows. We provide a review of the related literature in the following section. In Section 3, we provide the data analysis; and in Section 4, we show our main results and provide a further discussion.

\section{Literature Review and Research Hypotheses}

There are differing approaches to studying the determinants and leading indicators of banking crises in the literature. Some authors, e.g., (Eichengreen and Rose 1998; Kaminsky and Reinhart 1999), focus on macroeconomic shocks, while some others, e.g., (Kaminsky and Reinhart 1999), examine the macroeconomic factors (e.g., the ratio of domestic credit to nominal GDP, the real interest rate on deposits, the ratio of lending-to-deposit interest and the deficit as a percentage of the GDP, among others). In emerging markets, banking crises are associated with four main macroeconomic factors: macroeconomic volatility (e.g., large relative price changes, trade fluctuations, interest rates,

1 Bank restructuring is a process that incorporates a series of measures-namely, macroeconomic, microeconomic, institutional, and regulatory_taken to restore problem banking systems (Sheng 1996). 
and changing capital flows), connected lending, government involvement and the failure of prudential regulation (Eichengreen and Rose 1998).

The recent literature analysing banking crises complements the previous analysis by considering both bank specific and macroeconomic variables, e.g., (Elsinger et al. 2006; Oet and Ong 2011; Lang and Schmidt 2016). Specifically, Elsinger et al. (2006) developed a framework in which they identify that the main sources of systemic risk are the level of correlation of a bank's portfolio exposure, high bankruptcy costs and ineffective crisis resolution strategies.

In recent years, we found large developments in early warning systems that combine macroeconomic and microeconomic variables. For instance, Oet and Ong (2011) included bank-specific and macroeconomic variables to identify imbalances that could be associated with bubbles that explain financial stress (e.g., securitization, the currency exchange rate concentration, bank capital at risk, the economic value of loan portfolio, leverage, GDP, property, investments, the interest rate, credit to GDP, solvency and credit). This holistic approach can be observed in the recent publications on early warning systems by several central banks, e.g., (Borio et al. 2018; Nyman et al. 2018). In our study, we follow this approach by selecting regulatory, macroeconomic and bank-specific variables.

Across the literature we find a broad spectrum of variables that explain bank risk. To conduct a systematic analysis and classification of these variables, we use the CAMEL (Capital, Asset Quality, Management, Earnings and Liquidity) $)^{2}$ rating system. This rating system was introduced in the 1980s by US supervisors for the on-site examination of banking institutions, and it allows supervisors to assign financial institutions a rating based on different variables. This rating enables comparisons of banks with their peers over time (Stackhouse 2018).

The CAMEL rating is extensively used in the literature, e.g., (Chiaramonte et al. 2015; Stiroh and Rumble 2006; Mäkinen and Solanko 2017). The CAMEL classification is also applied by several international banking supervisors to classify the variables in their Early Warning Systems, e.g., (Lang et al. 2018; Nyman et al. 2018).

Following the CAMEL procedure, we develop five hypotheses.

\subsection{Capital (Adequacy)}

Capital can be defined as the variable that determines a financial institutions' robustness to withstand shocks to its balance sheet (Gelos 2015). Capital can also be defined as a measure of a bank's sensitivity to difficulties, since the bank's losses end up reducing bank capital (Lang and Forletta 2019). However, there is no consensus on the effect of capital ratios on bank risk. Higher capital requirements are still under debate, as there is no agreement as to how capital changes could affect the likelihood of a new crisis (D'Erasmo 2018).

Recent literature shows a negative relationship between a bank's capital and its risk, i.e., (Laeven et al. 2016; Acosta-Smith et al. 2018), supporting the Basel Accords ${ }^{3}$. Acosta-Smith et al. 2018 state that higher capital requirements create more stable and resilient banks, while Laeven et al. (2016) provide empirical evidence that better capitalized banks tend to have lower risk, with this effect being more pronounced for large financial institutions.

2 This system allows the supervisors to gather information in a systematic way that will result in the evaluation of bank financial conditions. The CAMEL rating is a uniform rating system, which covers five categories of banks' general conditions to be examined (Capital, Asset Quality, Management, Earnings and Liquidity) (Stackhouse 2018). Within each category or component there is a rating system from 1 to 5 to measure the level of impact that this risk component can have on the bank: 1 represents the highest rating and the lowest level of supervisory concern, while 5 represents the most critically deficient level of performance and therefore the highest degree of supervisory concern.

3 The Basel III Accords require national authorities in each jurisdiction to monitor credit growth and make assessments of whether such growth is excessive. When this credit growth is disproportionate, banks will be required to have a buffer of capital (the so-called countercyclical capital buffer) to achieve the broader macroprudential goal of protecting the banking sector from periods of excess aggregate credit growth that have often been associated with the build-up of system-wide risk. This buffer ensures not only that individual banks remain solvent through a period of stress, but also that the banking sector in the aggregate has the capital on hand to help maintain the flow of credit in the economy. 
Some authors are more critical of the Basel criteria, which they consider to be excessively reductionist. In this vein, Hughes and Mester (1998) state the need to also consider bank efficiency when looking at capital and risk, suggesting that more efficient banks should be allowed to have more flexibility with respect to their capitalization. Similarly, Calem and Rob (1999) show a non-linear (U-shaped) relationship between capital and risk, suggesting that imposing stricter regulatory requirements on banks is a good strategy for regulators only if banks hold a relatively low amount of capital. In contrast, if banks are already highly capitalized, an increase in capital would lead to a higher risk exposure. Schliephake (2016) confirms that capital requirements seem to reduce risk unless banks operate in a highly competitive environment during and in the aftermath of a crisis. In such a scenario, stricter capital requirements could increase bank risk exposure.

Finally, Gelos (2015) and (Nguyen et al. 2019) found a positive relationship between bank capitalization and risk. Gelos (2015) stated that the bank capital ratio can also be used to explain the propagation speed of distress across financial institutions. Likewise, (Nguyen et al. 2019) suggested that larger capital ratios could induce banks to increase risk.

Although in emerging economies capital requirements have not limited risk intake during expansion cycles (Rojas-Suarez 2001), it is necessary for Latin American banks to hold capital to cope with the volatility of the depositors' demands. Latin American banks can use capital reserves as liquidity buffers for these moments in which the risk increases because of the increase in depositors' demands due to special market volatility (Rojas-Suárez and Weisbrod 1996).

Usually, Capital Adequacy is measured through reversed leverage proxies, e.g., (López 1999; Stackhouse 2018; Bornemann et al. 2014). Therefore, we select the ratio Equity to Total Assets (E/TA) as a proxy for Capital Adequacy (Uhde and Heimeshoff 2009; Chortareas et al. 2011). As equity decreases, with total assets remaining constant, the proportion of debt of a bank will rise, causing higher leverage and increasing their risk (Federico and Vázquez 2012). Therefore, we state the following:

Hypothesis 1 (H1). There is a negative relationship between capital adequacy measured through the E/TA of a bank and its risk.

\subsection{Asset (Quality)}

According to the Federal Deposit Insurance Corporation", asset quality measures "the quantity of existing and potential credit risk associated with the loan portfolio, other real estate owned and other assets, as well as off-balance sheet transactions".

Assets can be affected by the market valuation and other risks (i.e., reputational, compliance or strategic risk), which can affect the assets' pricing (Rono and Traore 2018). There is a broad consensus concerning the existence of an inverse relationship between a bank's asset quality and its risk (Agresti et al. 2008).

In the literature, we can find different measures of asset quality, such as the following examples: non-performing loans to total gross loans, the sectoral distribution of loans to total loans, and the share of loan loss provisions to total average loans (Betz et al. 2013). Due to the limited data on non-preforming loans, we use Net Loans to Total Assets (NL/TA) as a proxy of asset quality. As we will develop in more detail in Section 3, our sample is constituted only by commercial banks, which tend to decrease lending to improve solvency ratios (Maurin and Toivanen 2012).

Another reason to use the NL/TA ratio as a proxy of asset quality is to analyse the lending focus of the institution in comparison to the overall business. Based on recent experiences, it is not necessarily beneficial for commercial banks to venture into non-traditional businesses (e.g., pensions, insurance, asset management, and investment banking, among others) to increase their profitability. Well-known commercial banks such as NatWest, Barclays and Deutsche Bank failed in these ventures and finally

4 https://www.fdic.gov/. 
returned to their original retail business. We support Miller (1998), who states that the idiosyncrasies of each business should make commercial and investment banking separate.

Poor asset quality in a bank will lower interest income, increase provisions, and affect the regulatory capital of a bank (Baudino et al. 2018). An increase in a bank's regulatory capital will affect its profitability and, by extension, the bank risk. Thus, we hypothesize the following:

Hypothesis 2 (H2). There is a negative relationship between the asset quality (NL/TA) of a bank and its risk.

\subsection{Management (Quality)}

Management measures the performance of the individuals in leadership roles at a bank. Regulators expect a bank to operate in a safe and sound manner, promoting a culture of compliance (Stackhouse 2018).

Senior management and the board of directors, to a large extent, are responsible for the financial soundness and performance of the financial institution. Regulators aim to strengthen the quality of the management team responsible for oversight of the bank as it is relevant factor in the process of risk management. Regulators have standards for banks manager in place to be fulfilled (Van Greuning and Sonja 2009).

Management is proxied in the literature by the characteristics of board-members, the CEO, and the chairperson, but also by quantitative ratios such as the cost to income ratio, earnings, the interest margin, and efficiency, among others (Petropoulos et al. 2017; Demsetz and Strahan 1997; Stiroh and Rumble 2006).

We use the Cost to Income ratio (CostI) to measure the management efficiency (BIS 2017; Francis 2014). More efficient banks tend to have lower average costs and lower cost-to-income ratios (Huljak et al. 2019), which are further expected to reduce the probability of a bank failure (Betz et al. 2013).

Banks with higher costs and lower levels of efficiency may be tempted to take on higher risks to compensate for the lost returns (Altunbas et al. 2007). Thus, we hypothesise the following:

Hypothesis 3 (H3). There is a positive relationship between "bad quality" management measured through CostI and a bank's risk.

\subsection{Earnings}

Earnings and profitability indicators are used to assess the financial health and monitor the efficient allocation of a bank's resources (Agresti et al. 2008). Banks that lose money over significant periods of time do not remain in business. Like other firms, banks do not stay in business unless they are profitable (Stackhouse 2018). Subsequently we can consider that more profitable banks have less propensity to undertake risk-taking incentives (Jensen and Meckling 1976).

However, during the recent financial crisis (2008), some highly profitable financial institutions proved to have engaged in risky investments. Martynova (2015) showed that highly profitable banks may have incentives to take on risky investments, as they can borrow greater amounts, thus accumulating larger risks. Another incentive for profitable banks to assume more risk is due to the lack of competition. Banks with a dominant position in the market can engage risk in alternative activities (Boyd and Nicoló 2005; Carlson and Mitchener 2006; Calomiris and Stephen 2013). An increase in bank competition could lead to a more expensive cost of capital, which could encourage risk taking (Altunbas et al. 2007; Lee and Hsieh 2013). Banks need stable and increasing profits. To obtain stable profitability, a bank must manage its risk, capital, and profitability to develop a business that augments capital resources over time (Van Greuning and Sonja 2009).

Some common metrics to proxy this category are the return on assets, the return on equity, e.g., (Altunbas et al. 2007; Lee and Hsieh 2013), interest margin to gross income, or non-interest 
expenses to gross income, e.g., (Agresti et al. 2008; Petropoulos et al. 2017). To measure Earnings, we use the Return on Equity (ROAE). This ratio measures the profitability of a bank's assets.

For our fourth hypothesis, we state the following:

Hypothesis 4 (H4). There is a negative relationship between bank profitability measured by ROAE and its risk.

\subsection{Liquidity}

Liquidity is related to the fundamental maturity transformation mission of a bank, which consists of transforming deposits and other liabilities into loans. Since the maturity of deposits and loans can differ, the bank needs to manage its liquidity by meeting deposit outflows whiel at the same time satisfying the demand for loans (Stackhouse 2018). However, during the recent financial crisis of 2008, when the European Central Bank (ECB) cut interest rates to below zero-making it expensive for banks to have deposits at the central bank-banks allocated the liquidity to assets, which increased the home-bias risk. This was particularly the case for banks with a high share of retail deposit funding and/or located in lower-rated countries (Macchiarelli 2018).

Petropoulos et al. (2017) and Köhler (2012) measure liquidity by comparing loans to different types of assets (e.g., loans to customer deposits, loans to total assets, and loans to volatile liabilities). Furthermore, Federico and Vázquez (2012) used the liquidity coverage ratio to show the relationship between a bank's dependence on short-term funding to finance the expansion of their balance sheet and their risk. Additionally, Van Greuning and Sonja (2009) determined that the liquidity risk of a bank is related to the bank's dependence on limited sources of funding.

Similar to Petria et al. (2015) and Federico and Vázquez (2012), we proxy liquidity using the Loans to Customer Deposits (L/CD) ratio. Petria et al. (2015) and Federico and Vázquez (2012) showed that banks with a dependence on short-term funding to finance their balance sheet in the period prior to a crisis are more likely to fail during the crisis. A bank with an $L / C D$ ratio above $100 \%$ is financing its loans with wholesale funding. Wholesale funding is less stable than customer deposits and could trigger an increase in the bank's funding liquidity risk (Bonfim and Kim 2012). Therefore, our last hypothesis posits the following:

Hypothesis 5 (H5). There is a positive relationship between the "illiquidity" of a bank as measured by its $L / C D$ and its risk.

Although previous results of the bank risk determinants remain inconclusive in the literature, based on the previous analysis, and taking into consideration that we are focusing on commercial banks located in Latin America, we expect well-capitalized, loan-focused (traditional bank), well-managed, profitable and liquid banks to have better Z-score ratios, and, consequently, lower risk.

\section{Data and Methodological Aspects}

\subsection{Sample}

We chose banks based on the available data in the Bankscope database maintained by Bureau Van Dijk (now Orbis Bank Focus). To minimize any incoherence and possible bias related to the bank business idiosyncrasies, we included only commercial banks in our sample. Moreover, to limit the potential for selection bias, we included banks that ceased their activities and others that might have changed their name due to an acquisition or further structural changes in the sample.

The range of the period we covered was from 1999 to 2013, which includes the crises in Argentina from 2001 to 2003 and in Uruguay from 2002 to 2005. The countries selected were the sovereign states categorized as Latin America (see Table 1). Nevertheless, four countries could not be included, since there was no information about their banks (Cuba, El Salvador, Haiti and Nicaragua). 
Table 1. Distribution of the observations across countries.

\begin{tabular}{ccc}
\hline Country & Observations & \% of Observations per Country \\
\hline Argentina & 1500 & $11.22 \%$ \\
Bolivia & 255 & $1.91 \%$ \\
Brazil & 3165 & $23.68 \%$ \\
Chile & 780 & $5.84 \%$ \\
Colombia & 1185 & $8.87 \%$ \\
Costa Rica & 690 & $5.16 \%$ \\
Ecuador & 420 & $3.14 \%$ \\
Guatemala & 615 & $4.60 \%$ \\
Honduras & 390 & $2.92 \%$ \\
México & 885 & $6.62 \%$ \\
Panama & 1590 & $11.90 \%$ \\
Peru & 540 & $4.04 \%$ \\
Uruguay & 510 & $3.82 \%$ \\
Venezuela & 840 & $6.29 \%$ \\
\hline
\end{tabular}

Source: Authors' own. Data source from Bureau Van Dijk (Bureau Van Dijk and Fitch 2013).

Entities with abnormal ratios or extreme values were eliminated from the sample as outliers. The criterion used to remove observations was that they were below the lower bound or above the upper bound. The formula for the lower bound was $\mathrm{Q}^{5} 1-1.5^{*} \mathrm{IQD}^{6}$. The formula to calculate the upper bound was Q3+1.5* IQD.

\subsection{Business Model Classification}

We used the Bank for International Settlements (BIS) Bank business model classification (Roengpitya et al. 2014) to select only retail-commercial banks. All banks from the sample needed to fulfil specific conditions to be classified as "commercial". Following Roengpitya et al. (2014), we selected those banks from our sample with ratios of growth of gross loans to growth of total assets, deposits to total assets, and stable funding that were higher than those from trading banks (a trading bank would have ratios of approximately $25.5 \%,-38 \%$, and $48.6 \%$, respectively). Additionally, we chose banks with proportions of Interbank Lending to total assets divided by Interbank liabilities to total assets and Trading to total assets that were lower than the ratios of trading banks (a trading bank would have ratios of approximately $21.8 \%, 19.1 \%$, and $17.3 \%$, respectively).

\subsection{Variables}

\subsubsection{Dependent Variable}

The Z-score is our primary measurement of an individual banks' risk. The Z-score measures the distance to default of a bank from an accounting point of view and the inputs to the calculation are the return on assets and the volatility of the return on assets. The higher the $Z$-score ratio is, the greater the distance to default and, consequently, the lower the risk; conversely, the closer the Z-score is to zero, the higher the risk and the greater the probability of default. Therefore, the Z-score is indirectly proportional to bank risk.

It is common in the literature to use the Z-score to measure bank risk (Maudos 2017; Uhde and Heimeshoff 2009; Ravi and Ravi 2007). Recently, Sherbo and Smith (2013) analysed the Z-scores of the financial crisis period (from December 2007 to June 2009), proving that this risk measurement is significant with $99 \%$ confidence.

\footnotetext{
Quartile.

Interquartile Distance Q1-Q3.
} 
We calculate the Z-score as follows:

$$
Z-\text { score } i, t=\frac{R O A A i, t+E T A i, t}{\sigma(R O A A) i, t}
$$

where $R O A A_{i, t}$ represents the return on average assets of bank I in year $t, E T A_{i, t}$ denotes the ratio of equity to total assets and $\sigma(R O A A)$ is the standard deviation of the return on total average assets.

Since the Z-score is highly skewed, we use the natural logarithm of the Z-score (Laeven and Levine 2009; Liu et al. 2013). Cihák and Schaeck (2007) proved that the frame for calculating the Z-score in their sample did not affect their results, and Yi (2012) computed the Z-score for two consecutive periods. Thus, we adjusted the Z-score calculation to use a two-year rolling window to increase the number of observations.

\subsubsection{Explanatory Variables}

As we have previously stated in the Literature review section, we rely on the CAMEL rating system to select our explanatory variables. We present the description of the variables and expected signs in Table 2.

The first CAMEL variable proxy we used for the Bank's Capital was the E/TA. We expected a negative relationship between bank capitalization and the bank risk, since a lower $E / T A$ means higher leverage, which makes the institution less resilient to shocks (Mäkinen and Solanko 2017). In addition, the $E / T A$ ratio is highly correlated with the Basel III regulatory definition of the leverage Ratio (ECB 2016).

Asset quality was examined through the NL/TA ratio, since banks with higher NL/TA ratios should be able to generate more interest revenue (García-Herrero et al. 2009), and bank profitability is a key component to increasing an institution's financial stability (ECB 2016).

The management quality of a bank was measured by CostI. An increase in CostI is expected to increase the probability of a bank failure (Betz et al. 2013; Maudos and Guevara 2004; Demsetz and Strahan 1997).

To measure a bank's earnings, we used ROAE. We expected a negative sign for the relation between the ROAE and distress, since increased profitability reduces the likelihood of a distress event (Altunbas et al. 2007; Van Greuning and Sonja 2009).

Illiquidity was proxied by the $L / C D$ ratio (Bonfim and Kim 2012). The relationship between the liquidity and bank risk was expected to be negative, since banks that finance their loan portfolios with short term liabilities may be exposed to refinancing problems in scenarios of macroeconomic stress, since in these circumstances banks may find it difficult to raise short-term funds and customer/wholesale deposits, eventually incurring deposit drainages (Chiaramonte et al. 2015). 
Table 2. Variable description.

\begin{tabular}{|c|c|c|c|}
\hline Classification & Variable & Notation & References \\
\hline Risk & Z-score & Z-score & $\begin{array}{l}\text { Lapteacru (2017); Wolfe et al. } \\
\text { (2007); Maudos (2017); Sherbo and } \\
\text { Smith (2013); Ravi and Ravi (2007); } \\
\text { Laeven and Levine (2009); Liu et } \\
\text { al. (2013) }\end{array}$ \\
\hline Capital & Equity to Total Assets & $E / T A \%$ & $\begin{array}{l}\text { Federico and Vázquez (2012); } \\
\text { Uhde and Heimeshoff (2009); } \\
\text { Chortareas et al. (2011) }\end{array}$ \\
\hline Asset Quality & Net Loans to Total Assets & $N L / T A \%$ & $\begin{array}{l}\text { Altunbas et al. (2007); Petropoulos } \\
\text { et al. (2017); Betz et al. (2013) }\end{array}$ \\
\hline Management & Cost to Income Ratio & $\operatorname{CostI} \%$ & $\begin{array}{l}\text { Francis (2014); Petropoulos et al. } \\
\text { (2017) }\end{array}$ \\
\hline Earnings & Return on Avg. Equity & $R O A E \%$ & $\begin{array}{l}\text { Altunbas et al. (2007); Lee and } \\
\text { Hsieh (2013) }\end{array}$ \\
\hline Liquidity & $\begin{array}{l}\text { Loans to Customer } \\
\text { Deposits }\end{array}$ & $L / C D \%$ & $\begin{array}{l}\text { Petria et al. (2015); Federico and } \\
\text { Vázquez (2012); Köhler (2012); } \\
\text { Van Greuning and Sonja (2009) }\end{array}$ \\
\hline Bank Concentration & $\begin{array}{l}\text { Herfindahl-Hirschman } \\
\text { Index }\end{array}$ & $H H I$ & Uhde and Heimeshoff (2009) \\
\hline \multirow{3}{*}{ Regulation } & Activity restriction index & Ares & Barth et al. (2004) and updates \\
\hline & Capital stringency & CStr & Barth et al. (2004) and updates \\
\hline & $\begin{array}{l}\text { Official supervisory } \\
\text { power }\end{array}$ & OSP & Barth et al. (2004) and updates \\
\hline \multirow{7}{*}{ Macroeconomic } & Private Monitoring & PriM & Barth et al. (2004) and updates \\
\hline & $\begin{array}{l}\text { Domestic credit to the } \\
\text { private sector (as \% of } \\
\text { GDP) }\end{array}$ & $D C P S$ & $\begin{array}{l}\text { Demirgüç-Kunt and Detragiache } \\
\text { (1998) and updates; Kaminsky and } \\
\text { Reinhart (1999) }\end{array}$ \\
\hline & Real interest rate & Int & $\begin{array}{l}\text { Demirgüç-Kunt and Detragiache } \\
\text { (1998); Uhde and Heimeshoff } \\
\text { (2009) }\end{array}$ \\
\hline & Inflation \% & Infl \% & $\begin{array}{l}\text { Demirgüç-Kunt and Detragiache } \\
\text { (1998); Davis et al. (2011) }\end{array}$ \\
\hline & Current Accounts & CurrAcc \% & Gertler et al. (2012) \\
\hline & $\begin{array}{l}\text { Real GDP growth rate } \\
\text { (Annual percent change) }\end{array}$ & GDPgrow & $\begin{array}{l}\text { World Development Indicators } \\
\text { (WDI); Demirgüç-Kunt and } \\
\text { Detragiache (1998) }\end{array}$ \\
\hline & Unemployment rate & Unpl \% & $\begin{array}{l}\text { A. Uhde, Uhde and Heimeshoff } \\
\text { (2009) }\end{array}$ \\
\hline Size & Total Assets & $T A$ & $\begin{array}{l}\text { Kleinov et al. (2014); Boyd and } \\
\text { Prescott (1986); Araújo and Leao } \\
\text { (2013) }\end{array}$ \\
\hline
\end{tabular}

\subsubsection{Control Variables}

The differences in the economic, political and regulatory frameworks of countries justify controlling for macroeconomic and regulatory variables in this analysis. Our research approach captures a holistic view of the banking crises considering macro and bank specific variables, which is in line with the research by Lund-Jensen (2012), who found that the level of systemic risk depends on macroeconomic and bank specific factors. Similarly, in their analysis of the early warnings signs of banking crises, Demirgüç-Kunt and Detragiache (1998) found the impacts of macroeconomic factors and that crises tend to emerge in scenarios with weak macroeconomic conditions, including low growth, high inflation, high real interest rates, a vulnerable balance of payments, explicit deposit insurance, and weak law enforcement. 
Moreover, Reinhart and Rogoff (2013) concluded that the there was a correlation between the peaks in the current account balance and new defaults on sovereign debt. Similarly, Valencia and Laeven (2008) showed that most banking crises occurred in countries with large current account deficits, while Kauko (2012) established that credit growth combined with current account deficits contributed to vulnerabilities in the banking system. Thus, we controlled for Current Accounts (CurrAcc).

We further controlled for Domestic Credit to the Private Sector (DCPS), since it plays an economically and statistically significant role in predicting subsequent crises. Obstfeld (2012) concluded that across all types of crises, the domestic credit to output was identified as the one variable with an important role.

GDPgrowth is included in most model specifications, irrespective of the geographic location of the banking crisis. Davis et al. (2011) indicated that crises occur in periods during which the GDP growth rate is low and interest rates, inflation and fiscal deficits are high. This idea was reinforced by Demirgüç-Kunt and Detragiache (1998) who proved that economic growth can be used to predict crises since, in most cases, the GDP growth rate slows down immediately before a crisis.

Chinn and Dooley (1997) analysed how crises in Latin America were generally preceded by a large foreign speculative capital inflow, which does not necessarily follow interest rate differentials across currencies. Fiscal shocks can increase the destabilization of domestic interest rates, leading to expected inflation and distorting the domestic deposit demand (Gavin and Ricardo 1998). Additionally, in a context with high interest rates, their reduction could induce the banks to lower their lending standards in search of a better yield (Lamas and Mencía 2019). Therefore, we controlled for the interest rate (Int) in the period studied across the different countries.

In their conclusions regarding how weak macroeconomic conditions affect systemic banking crises, Demirgüç-Kunt and Detragiache (1998) stated that high inflation can be one of the main causes of systemic banking problems. In the same way, Davis et al. (2011) examined how excessive inflation (above 30\%) doubles the chances of a systemic banking crisis in Latin America compared to other regions in the world. Finally, Duca and Peltonen (2013) considered inflation to be one of the relevant variables to address country-specific macro financial indicators in the case of emerging economies. We therefore controlled for Inflation \% (Infl) in our multivariate analysis.

We further controlled for Unemployment rate \% (Unemp), which has been related to bank asset quality in the previous literature (Bofondi and Ropele 2011). A higher unemployment rate may affect the bank risk associated with lending (Hancock and Wilcox 1994).

Finally, we selected four indicators from the World Bank database on Bank Regulation and Supervision developed by Barth et al. (2004) to control for regulatory differences across Latin American countries in our empirical specification, since the literature suggests that these indicators may affect bank risk.

The Activity Restriction Index (Ares) includes restrictions on securities, insurance, and real estate activities, plus restrictions on banks owning and controlling nonfinancial firms. Capital Stringency (CStr) captures whether the capital requirement reflects certain risk elements and deducts certain market value losses from capital before minimum capital adequacy is determined.

Official Supervisory Power (OSP) is connected to whether supervisors have the authority to take specific actions to prevent and correct problems and circumstances that can help to prevent banks from engaging in excessive risk-taking behaviour, thus improving bank development, performance and stability. Private Monitoring (PriM) levels show the degree to which banks are forced by the supervisory authorities to disclose accurate information to the public, and whether there are incentives to increase market discipline. These regulations, which promote and facilitate the private monitoring of banks, are associated with better banking-sector outcomes.

Following Uhde and Heimeshoff (2009), we controlled for Industry concentration using the Herfindahl-Hirschman Index (HHI). In their investigation, Uhde and Heimeshoff (2009) showed that there is a negative relationship between market concentration and European banks' financial robustness. 
We further controlled for bank size using the natural logarithm of its total assets (TA). Across the literature, several studies have indicated that larger banks are capable of improving their profitability levels and capital buffers, which decreases their assumed risk intake (Kleinov et al. 2014). Additionally, these banks are capable of benefitting from economies of scale and scope (Boyd and Prescott 1986). Araújo and Leao (2013) indicate that larger institutions, as measured through the TA, in Brazil tend to be less risky.

\subsubsection{Methodology}

We applied the GMM-System estimator developed by Arellano and Bover (1995) and Blundell and Bond (1998), which is also referred to as the system-GMM estimator. Since some bank-specific factors of bank risk can be endogenous, some other unobserved characteristics could cause correlations between the coefficients of the explanatory variables. We applied the GMM-System estimator in a two-step estimation procedure with finite-sample corrected standard errors, as proposed by Windmeijer (2005) and Baselga-Pascual et al. (2015).

The system-GMM estimator addresses endogeneity by means of suitable instruments. We consider the bank-specific variables as endogenous covariates by employing the lagged first differences of the bank-specific explanatory variables as instruments for the equation in levels and the lagged values of the explanatory variables in levels as instruments for the equation in differences (in line with Arellano and Bover 1995; Blundell and Bond 1998). Industry concentration and macroeconomic variables are treated as strictly exogenous following the authors Delis and Staikouras (2011) and Baselga-Pascual et al. (2015). Our baseline equation is as follows:

$$
Y_{i, j, t}=\alpha+\delta \cdot Y_{i, j, t-1}+\beta \cdot B S_{i, j, t}+\gamma \cdot M_{j, t}+\theta \cdot R_{j . t-1}+\eta \cdot L_{i, j, t}+\varepsilon_{i, j, t}
$$

where $Y$ denotes the variable used to measure the risk of bank $i$ in country $j$ at year $t ; Y_{i, j, t-1}$ represents the lagged value of the dependent variable; $\delta$ measures the speed of mean reversion; $B S_{i, j, t}$ and $M_{j, t}$ denote, respectively, the bank-specific and the industry and macroeconomic variables considered in our study; $R_{j, t-1}$ refers to several bank regulation and supervision control variables; and $\beta, \gamma$, and $\theta$ are vectors of coefficient estimates. Finally, $\varepsilon_{i, j, t}$ is the disturbance term.

Additionally, and similar to earlier studies on bank risk, e.g., (Baselga-Pascual et al. 2015; Foos et al. 2010, to increase the robustness of our original results, we alternatively applied the ordinary least squares (OLS) regression with fixed year and country effects. However, due to the nature and superiority of the system-GMM estimator (it is able to use lagged values of the dependent variable and capable of treating endogenous, bank-specific variables instrumented by their own lagged values), we will prioritize the results of the GMM-System above those of the OLS.

\section{Empirical Results}

Table 3 provides the results of the system-GMM estimator. Based on the sign and significance of the coefficients, we can confirm Hypotheses 1, 2 and 5. 
Table 3. System-GMM estimators of the Z-score.

\begin{tabular}{|c|c|}
\hline Variables & Z-Score \\
\hline Constant & $\begin{array}{c}112.53 \\
(211.62)\end{array}$ \\
\hline ETA & $\begin{array}{c}3.01^{* * *} \\
(1.2)\end{array}$ \\
\hline NLTA & $\begin{array}{l}1.67 \text { ** } \\
(0.76)\end{array}$ \\
\hline CostI & $\begin{array}{l}-0.19 \\
(0.31)\end{array}$ \\
\hline$R O A E$ & $\begin{array}{l}-3.39 \\
(2.64)\end{array}$ \\
\hline$L C D$ & $\begin{array}{c}-0.24^{* *} \\
(0.12)\end{array}$ \\
\hline HHI & $\begin{array}{c}-289.3 \\
(424.23)\end{array}$ \\
\hline Ares & $\begin{array}{c}-10.86 \\
(9.51)\end{array}$ \\
\hline CStr & $\begin{array}{l}-0.53 \\
(5.95)\end{array}$ \\
\hline OSP & $\begin{array}{c}-2.41 \\
(8)\end{array}$ \\
\hline PriM & $\begin{array}{l}-3.24 \\
(14.82)\end{array}$ \\
\hline DCPS & $\begin{array}{l}-0.57 \\
(0.82)\end{array}$ \\
\hline Int & $\begin{array}{l}2.31 * \\
(1.31)\end{array}$ \\
\hline Infl & $\begin{array}{c}0.23 \\
(2.09)\end{array}$ \\
\hline CurrAcc & $\begin{array}{c}1.7 \\
(0.81)\end{array}$ \\
\hline GDPgrowth & $\begin{array}{l}-0.56 \\
(1.57)\end{array}$ \\
\hline Unemp & $\begin{array}{l}-1.66 \\
(4.08)\end{array}$ \\
\hline$T A$ & $\begin{array}{c}25.15 * * \\
(12.53)\end{array}$ \\
\hline $\mathrm{AR}_{1}$ & -1.96 \\
\hline $\mathrm{AR}_{2}$ & 0.95 \\
\hline Sargan & 332.39 \\
\hline Hansen & 111.74 \\
\hline $\mathrm{F}$ & $1.90^{* *}$ \\
\hline $\begin{array}{c}\text { Number of } \\
\text { observations }\end{array}$ & 525 \\
\hline
\end{tabular}

Notes: The table reports the determinants of bank risk in Latin America during the period from 1999 to 2013 using the GMM estimator developed by Arellano and Bover (1995) and Blundell and Bond (1998). The risk characteristics are classified using the CAMEL. Table 2 provides a description of the explanatory variables. The bank level variables are considered to be endogenous (ETA, NLTA, CostI, ROAE, LCD, and TA) while the macroeconomic/regulatory are considered to be exogenous (HHI, Ares, CStr, OSP, PriM, DCPS, Int, Infl, CurrAcc, GDPgrowth, and Unemp). We report heteroskedasticity-consistent asymptotic standard errors in parentheses, and the significance levels are indicated as follows: ${ }^{* * *}=$ significant at the $1 \%$ level, ${ }^{* *}=$ significant at the $5 \%$ level, and $*=$ significant at the $10 \%$ level. Hansen is a test for over-identifying restrictions, which are asymptotically distributed as $\chi^{2}$ under the null hypothesis of no correlation between the instruments and the error term. Source Authors' own. Data Source from Bureau Van Dijk (Bureau Van Dijk and Fitch 2013).

First, looking at the E/TA, we observe a positive and significant relationship with the Z-score, which indicates that banks with less risk have higher $E / T A$ ratios, as we state in hypothesis 1 . This finding is in line with Laeven et al. (2016) and Acosta-Smith et al. (2018), showing that higher capital requirements 
relate to better capitalized banks, and a more resilient scenario. The Latin American financial system is particularly fragile due to the high volatility in capital inflows experienced in the past, which required the strengthening of capital adequacy requirements ${ }^{7}$. These capital inflows were accompanied by rapid expansions of bank credit and consumption booms which caused contractions and bust when the inflows were reversed (IMF 2015).

Second, we find a negative relationship between the NL/TA and bank risk. Consequently, we can confirm our second hypothesis, showing that asset quality is indicative of more lending and less risk. From this result, we can also conclude that within the commercial banks, a larger portfolio of loans is related to lower risk. This result could indicate that banks focused on the basic activity of maturity transformation tend to have less risk.

The fact that, in the past, Latin American banks replaced nonperforming loans with sizable portfolios of government bonds could contribute to explaining the negative relation between NL levels and banks risk. This reaction was caused due to the experience of high default rates from households and corporation lending (IMF 2015). However, government bonds exposure can be risky (BIS 2017). This exposure can hide efficiency issues from banks, as it presents limitations to allocating their resources through maturity transformation. This strategy consists of shifting a bank's portfolio risk towards sovereign exposure to maximize their returns (Gennaioli et al. 2013; Lamas and Mencía 2019).

Finally, illiquidity seems to be positively correlated with the bank risk (negatively correlated with the $Z$-score value). Thus, we can confirm our fifth hypothesis since the proxy $L / C D$ is statistically significant and positively related to bank risk in the GMM. Less liquid banks, i.e., those with lower proportions of their loan portfolios being financed by customers' deposits, take on more risk. Banks can experience an increase in risk levels when the liquidity levels decline or the proportion of loans to customer deposits increase, which amounts to the same thing. In the past, Latin America has experienced crises of liquidity. Latin American countries are characterised by a relatively high level of dollarization, large shares of bank deposits and loans denominated in dollars (Bolivia, Nicaragua, Paraguay, Peru and Uruguay, more than half of deposits and loans are denominated in dollars) and in some countries dollarization has even instigated currency substitution (Bolivia, Paraguay, Peru and Uruguay). Highly dollarized banking sectors can be characterized by higher insolvency levels and deposit volatility (De Nicolo et al. 2003), which helps to understand the higher proportion of liquidity levels needed by the Latin American banks. In fact, in a scenario of banking distress, depositors have an incentive to convert their deposits into cash and transfer them abroad. This behaviour was appreciated during the Uruguayan crisis of 2002 or the effects the Mexican crises of 1994 had in the Argentinian banks (De Brun and Gerardo 2005).

We cannot, however, confirm our third and fourth hypotheses. The coefficient of CostI is positive, but not significant, and this can be explained by the different cost structures of the institutions across the region. Additionally, the banking structure inefficiency in this area is left over from the high inflation periods. During times of high inflation, banks' revenues obtained from holding government bonds indexed to the overnight interest rate compensate for the deposit rate, which allows banks not to pay enough attention to the efficiency levels, and thus the costs across the region continue being high (Belaisch Agnes et al. 2005). Regarding the ROAE, we cannot confirm our hypothesis 4 due to the statistical insignificance of the coefficient.

Looking at the control variables, we find that the Int rate and the TA are significant. The interest rate seems to be negatively related to banks' risk intake, which can be easily understood due to the idiosyncrasy of the zone, where banks are used to working with high interest rates and larger spreads. In the same way, the TA seems to be negatively correlated with bank risk. In some of the

7 Chile adopted a banking law in 1986 restricting related lending and strengthening capital adequacy requirements. Brazil increased capital requirements for opening new banks. Prudential capital ratios were settled above the Basel minimum by Argentina, Brazil, and Venezuela; IMF (2015). 
larger economies of the zone, such as Brazil, there has been a consolidation process across the sector, which allows the institutions to achieve economies of scale and scope and become more efficient.

\section{Robustness}

To test the robustness of our results, we alternatively applied an OLS regression with fixed year and country effects (see Table 4). The results of the OLS confirm Hypotheses 1 and 2, showing significant and negative correlations between capital ratios, asset quality and bank risk, thus providing robustness to our results. However, based on the OLS regression, we cannot confirm Hypothesis 5. There are some differences regarding the control variables since TA and Int lose their significance. However, due to the higher accuracy of the GMM-system and the confirmation of Hypotheses 1 and 2, we find robust confirmation of the results.

Table 4. OLS for Z-score.

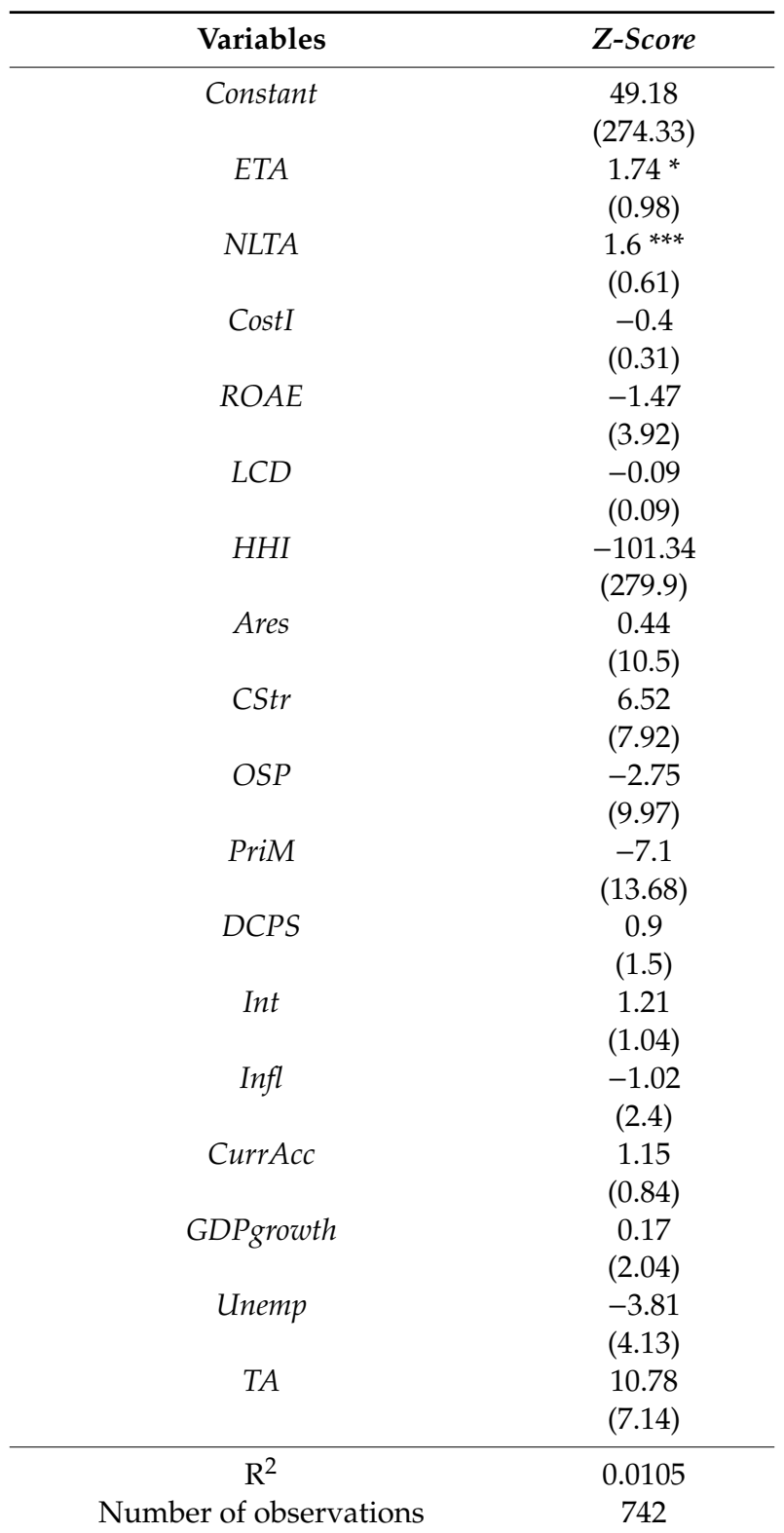

Notes: The table reports the determinants of bank risk in Latin America during the period from 1999 to 2013 using OLS. The risk characteristics are classified using the CAMEL. Table 2 provides a description of the explanatory variables. We report heteroskedasticity-consistent asymptotic standard errors in parentheses, and the significance levels are indicated as follows: ${ }^{* *}=$ significant at the $1 \%$ level, and ${ }^{*}=$ significant at the $10 \%$ level. Source Authors' own. Data Source from Bureau Van Dijk (Bureau Van Dijk and Fitch 2013). 


\section{Conclusions and Discussion}

In this paper, we examine the main bank risk determinants in Latin America. The conclusions of this study are relevant for regulators in their aim to reduce the spread and limit the consequences of financial crises.

This article empirically analyses the factors influencing the risk of commercial banks in Latin America from the period from 1999 to 2013 using a panel data set of 13,365 observations. The period of analysis includes the systemic banking crises in Argentina (2001-2003) and Uruguay (2002-2005). We proxy risk using the measure of the Z-score. The bank risk determinants are classified following the CAMEL Rating. We complement our analysis by controlling for macroeconomic and regulatory variables. Additionally, we perform a robustness check by applying an alternative methodology that provides similar results to our original model.

One innovative factor of our analysis is the classification of the different bank business models in the sample by selecting only commercial banks, following Roengpitya et al. (2014). We further examine the bank-specific, regulatory, and macroeconomic determinants of bank risk and how they affect risk as measured by the Z-score (Maudos 2017; Uhde and Heimeshoff 2009; Ravi and Ravi 2007; Sherbo and Smith 2013). We apply a quantitative approach using the system-GMM estimator, developed by Arellano and Bover (1995) and Blundell and Bond (1998), to analyse dynamic panel models.

Supporting the previous literature, we find a negative relationship between a bank's capital adequacy, asset quality, liquidity, and risk.

According to our results, well-capitalized banks have lower risk. Several authors have shown that banks with strong equity levels are more resilient to shocks (ECB 2016; Gelos 2015). Therefore, it would be desirable, in the light of the Latin American financial markets' fragility, to increase their capital ratios.

We further show a negative relationship between the NL/TA and banks. This result might indicate that larger loan portfolios are related to stronger bank health levels, since they are more focused on traditional banking activities (Behn et al. 2019). Our results support the recent regulations in the United States (the Volcker rule), United Kingdom (the Vickers Commission report) and Europe (the Liikanen report) that imply restrictions on the universal banking model in favour of traditional banking.

Finally, we show that higher levels of liquidity lead to lower bank risk, supporting Petria et al. (2015) and Federico and Vázquez (2012), who identified that mismatched maturity between deposits and loans is a source of risk. Due in part to the dollarization of the economy, the past period of deposit runs, and macroeconomic imbalances, it is relevant to consider high liquidity levels for the Latin American region to mitigate bank risk.

We cannot confirm our third and fourth hypotheses. The different regulatory environments across the banks in our sample could affect CostI, which could explain the lack of significance of this variable. Despite bank profitability in general being associated with bank efficiency and lower risk (Xu et al. 2019), we conclude that the same cannot be extended to emerging markets. This finding was also reported by Rojas-Suarez (2001) in her analysis of financial indicators in emerging markets, where she highlights that neither profitability ratio nor the cost ratio are useful indicators for discerning between strong and weak banks in developing countries. These results show that the banks across this region have a specific idiosyncrasy regarding costs, since financial intermediation expenses in the region are particularly high (Calice and Zhou 2018).

With respect to macroeconomic variables, our results show a negative relationship between interest rates and bank risk. Contrary to some European countries, Latin American countries seem to have lower risk intake when higher interest rates exist, which shows the idiosyncrasy of the region and indicates that Latin American banks work better in high interest rates scenarios where they can be more selective in their asset allocation. We further find a negative relationship between bank size and risk.

In conclusion, the risk factors that affect financial institutions in Latin America are relevant topics of analysis since these institutions continue being confronted with significant challenges, including a 
weak economic environment, currency devaluation and interest rate volatility, that reduce profitability and increase risk.

A better understanding of the risk factors in the Latin American financial sector gains additional interest in the current weak global economy in which the rising policy uncertainty is slowing down Latin America's growth momentum. As a matter of fact, banks and regulators should closely and proactively monitor their financial intermediaries' risk intake in the economic slowdown caused by the tightening of global financial conditions, uncertainty of the COVID-19 pandemic and the commercial tensions in the global trade. As mentioned by the International Monetary Fund (IMF) director Kristalina Georgieva, Latin America has been hit particularly hard, with an expected contraction of 9.3 percent in 2020 (Georgieva 2020), which would doubtless spread to the banks and contribute to region growth.

Due to the chosen analysis approach, this study could present limitations. We focused on the main economic indicators at the bank level across commercial banks. It should be noted that some omitted variables, such as political factors and changes in governments could affect the policies in place and, therefore, bank risk.

Author Contributions: M.M.-M. and L.B.-P. conceived the presented idea. M.M.-M. developed the theory and performed the computations. L.B.-P. verified the analytical methods, encouraged M.M.-M. to investigate Z-score as the risk measure, and the use of GMM-System as the main methodology and supervised the findings of this work. All authors discussed the results and contributed to the final manuscript. All authors have read and agreed to the published version of the manuscript.

Funding: This research received no external funding.

Acknowledgments: We wish to thank Beatriz García Osma, Iñaki Peña, six anonymous referees, and conference participants at the XX AECA International Conference and the doctoral workshops of the University of Deusto for their valuable comments and suggestions. The financial support of the University of Deusto and National Research-Deiker is gratefully acknowledged. Part of this paper was written while L. Baselga-Pascual was visiting the University of Vaasa (Finland). We are deeply grateful to the XX AECA International Conference organizers for awarding this paper with the "differential certificate of scientific quality".

Conflicts of Interest: The authors declare no conflict of interest.

\section{References}

Acosta-Smith, Jonathan, Michael Grill, and Jan Hannes Lang. 2018. The Leverage Ratio, Risk-Taking and Bank Stability. ECB Working Paper 766: 1-74. [CrossRef]

Agnoli, Myriam Quispe, and Diego Vilán. 2008. Financing trends in Latin America. Bankfor International Settlements 36: 15-27. Available online: https://www.bis.org/publ/bppdf/bispap36.pdf (accessed on 7 September 2020).

Agresti, Ana María, Patrizia Baudino, and Paolo Poloni. 2008. The ECB and IMF indicators for the Macroprudential analysis of the banking sector: A comparison of the two approaches. ECB Occasional Paper Series 99: 1-54.

Aldasoro Iñaki, Claudio Borio, and Mathias Drehmann. 2018. Early warning indicators of banking crises: Expanding the family. BIS Quarterly Review 2018: 29-45.

Altunbas, Yener, Santiago Carbo, Edward P. M. Gardener, and Philip Molyneux. 2007. Examining the relationships between capital, risk and efficiency in European banking. European Financial Management 13: 49-70. [CrossRef]

Araújo, Gustavo, and Sergio Leao. 2013. Risco Sistêmico no Mercado Bancário Brasileiro—uma Abordagem pelo Método; Brasília: Banco Central do Brasil.

Arellano, Manuel, and Olympia Bover. 1995. Another look at the instrumental variable estimation of error-components models. Journal of Econometrics 68: 29-51. [CrossRef]

Banco de España. 2017. Financial Stability Report. Madrid: Bank of Spain.

Barth, James R., Gerard Caprio, and Ross Levine. 2004. Bank regulation and supervision: What works best? Journal of Financial Intermediation 13: 205-48. [CrossRef]

Baselga-Pascual, Laura, Antonio Trujillo-Ponce, and Clara Cardone-Riportella. 2015. Factors influencing bank risk in Europe: Evidence from the financial crisis. North American Journal of Economics and Finance 34: 138-66. [CrossRef]

Baudino, Patrizia, Orlandi Jacopo, and Zamil Raihan. 2018. The identification and measurement of non-performing assets: A cross-country comparison. FSI Insights on Policy Implementation 7: 6-22. 
Behn, Markus, Claudio Daminato, and Carmelo Salleo. 2019. A Dynamic Model of Bank Behaviour under Multiple Regulatory Constraints. ECB Working Paper, 2233. Available online: https:/www.ecb.europa.eu/pub/pdf/ scpwps/ecb.wp2233 \{\}f03ecad4e8.en.pdf (accessed on 18 November 2019).

Belaisch Agnes, Collyns Charles, Masi Paula De, Meredith Guy, Singh Anoop, Krieger Reva, and Rennhack Robert. 2005. Latin American Financial Systems: Crises and Reforms. International Monetary Fund (IMF) Working Papers. Washinton, DC: IMF.

Betz, Frank Silviu, Toumas A. Peltonen, and Peter Sarlin. 2013. Predicting Distress in European Banks. ECB Working Paper 1597. Available online: https://www.econstor.eu/handle/10419/154030 (accessed on 28 November 2018).

BIS. 2007. Evolving Banking Systems in Latin America and the Caribbean. Bank for International Settlements (BIS). Available online: https://www.bis.org/publ/bppdf/bispap33.pdf (accessed on 1 June 2018).

BIS. 2017. The Regulatory Treatment of Sovereign Exposures-Discussion Paper. Bank for International Settlements (BIS). Available online: https://www.bis.org/bcbs/publ/d425.pdf (accessed on 1 June 2018).

Blundell, Richard, and Stephen Bond. 1998. Initial conditions and moment restrictions in dynamic panel data models. Journal of Econometrics 87: 115-43. [CrossRef]

Bofondi, Marcello, and Tiziano Ropele. 2011. Macroeconomic Determinants of Bad Loans: Evidence from Italian banks. Bank of Italy Occasional Papers 89. [CrossRef]

Bonfim, Diana, and Moshe Kim. 2012. Liquidity Risk in Banking: Is There Herding? EBC Discussion Paper 2012: 24. [CrossRef]

Borio, Claudio, Piti Disyatat, Mikael Juselius, and Phurichai Rungcharoenkitkul. 2018. Monetary policy in the grip of a pincer movement. BIS Working Papers 706: 1-39.

Bornemann, Sven, Susanne Homölle, Carsten Hubensack, Thomas Kick, and Andreas Pfingsten. 2014. Visible Reserves in Banks Determinants of Initial Creation, Usage and Contribution to Bank Stability. Journal of Business Finance \& Accounting 41: 5-6.

Boyd, John H., and Gianni De Nicoló. 2005. The theory of bank risk taking, and competition revisited. Journal of Finance 60: 1329-43, Working Papers 12: 1. [CrossRef]

Boyd, John H., and Edward Prescott. 1986. Financial intermediary-coalitions. Journal of Economic Theory 38: 211-32. [CrossRef]

Bureau Van Dijk and Fitch. 2013. Available online: https://www.bvdinfo.com/es-es/ (accessed on 15 December 2017).

Calem, Paul, and Rafael Rob. 1999. The impact of capital-based regulation on bank risk-taking. Journal of Financial Intermediation 8: 317-52. [CrossRef]

Calice, Pietro, and Nan Zhou. 2018. Benchmarking Costs of Financial Intermediation around the World. Available online: http://blogs.worldbank.org/allaboutfinance/benchmarking-costs-financial-intermediation-aroundworld (accessed on 25 January 2020).

Calomiris, Charles, and Haber Stephen. 2013. Fragile by Design: The Political Origins of Banking Crises and Scarce Credit. Princeton: Princetown University Press.

Caprio, Gerard, and Daniella Klingebiel. 1997. Bank Insolvency: Bad Luck, Bad Policy or Bad Banking? Washinton, DC: The World Bank.

Carlson, Mark, and Kris James Mitchener. 2006. Branch banking, bank competition, and financial stability. Journal of Money, Credit and Banking 38: 1293-328. [CrossRef]

Chiaramonte, Laura, Ettore Croci, and Federica Poli. 2015. Should we trust the Z-score? Evidence from the European banking industry. Global Finance Journal 28: 111-31. [CrossRef]

Chinn, Menzie D., and Michael P. Dooley. 1997. Financial repression and capital mobility: Why capital flows and covered interest rate differentials fail to measure capital market integration. Monetary and Economic Studies 15: 81-103.

Chortareas, Georgeos E., Claudia Girardone, and Alexia Ventouri. 2011. Financial frictions, bank efficiency and risk: Evidence from the eurozone. Journal of Business Finance $\mathcal{E}$ Accounting 38: 259-87. [CrossRef]

Cihák, Martin, and Klaus Schaeck. 2007. How well do aggregate bank ratios identify banking problems? IMF Working Papers 7: 1. [CrossRef]

D'Erasmo, Pablo. 2018. Are higher capital requirements worth it? Curbs on bank leverage are intended to prevent bailouts but can slow economic growth. The challenge is to obtain precise estimates of the impact so policymakers can weigh the trade-off. Economic Insights (Federal Reserve Bank of Philadelphia) 3: 1.

Davis, E. Philip, Dilruba Karim, and Iana Liadze. 2011. Should multivariate early warning systems for banking crises pool across regions? Review of World Economics 147: 693-716. [CrossRef] 
De Brun, Julio, and Licandro Gerardo. 2005. To Hell and Back. Crisis Management in a Dollarized Economy: The Case of Uruguay. No 2005004, Documentos de trabajo. Montevideo: Banco Central del Uruguay.

Delis, Manthos, and Panagiotis K. Staikouras. 2011. Supervisory effectiveness and bank risk. Review of Finance 15: 511-43. [CrossRef]

Demirgüç-Kunt, A., and E. Detragiache. 1998. The Determinants of Banking Crises in Developing and Developed Countries. International Monetary Fund (IMF) Staff Papers 45: 81-109. [CrossRef]

Demsetz, Rebecca S., and Philip E. Strahan. 1997. Diversification, size, and risk at bank holding companies. Journal of Money, Credit and Banking 29: 300-13. [CrossRef]

Duca, Marco L., and Toumas A. Peltonen. 2013. Assessing systemic risks and predicting systemic events. Journal of Banking and Finance 37: 2183-95. [CrossRef]

ECB. 2016. Financial Stability Review; European Central Bank (ECB). Available online: https://www.ecb.europa.eu/ pub/pdf/fsr/financialstabilityreview201605.en.pdf (accessed on 7 September 2020).

Eichengreen, Barry, and Andrew Rose. 1998. Staying afloat when the wind shifts: External factors and emerging-market banking crises. National Bureau of Economic Research 6370. [CrossRef]

Elsinger, Helmut, Alfred Lehar, and Martin Summer. 2006. Risk assessment for banking systems. Management Science 52: 1301-14. [CrossRef]

Enoch, Charles, Bossu Wouter, Carlos Caceres, and Diva Singh. 2016. Financial Integration in Latin America. Washinton, DC: IMF.

Federico, P., and F. F. Vázquez. 2012. Bank funding structures and risk: Evidence from the global financial crisis. IMF Working Papers 12: 1. [CrossRef]

Foos, Daniel, Lars Norden, and Martin Weber. 2010. Loan growth and riskiness of banks. Journal of Banking and Finance 34: 2929-40. [CrossRef]

Francis, William. 2014. UK Deposit-Taker Responses to the Financial Crisis: What Are the Lessons? Available online: https://www.openaire.eu/search/publication?articleId=od___ 645:: 09830744c0311d77f1fdf4e3de953511 (accessed on 2 September 2020).

Galindo, Arturo, Alejandro Izquierdo, and Liliana Rojas-Suarez. 2010. Financial Integration and Foreign Banks in Latin America: How Do They Impact the Transmission of External Financial Shocks? (No. IDB-WP-116). Washinton, DC: Inter-American Development Bank (IDB), Available online: https://www.econstor.eu/handle/10419/89137 (accessed on 2 September 2020).

García-Herrero, Alicia. 1997. Monetary Impact of a Banking Crisis and the Conduct of Monetary Policy. IMF Working Papers 97. [CrossRef]

García-Herrero, Alicia, Sergio Gavilá, and Daniel Santabárbara. 2009. What explains the low profitability of Chinese banks? Journal of Banking and Finance 33: 2080-92. [CrossRef]

Gavin, Michael, and Hausmann Ricardo. 1998. Macroeconomic Volatility and Economic Development. In The Political Dimension of Economic Growth. International Economic Association Series. Edited by S. Borner and M. Paldam. London: Palgrave Macmillan. [CrossRef]

Gelos, Gaston. 2015. Financial Soundness Indicators. Washinton, DC: International Monetary Fund, Available online: http://portal.igpublish.com/iglibrary/search/IMFB0000071.html (accessed on 2 September 2020).

Gennaioli, Nicola, Andrei Shliefer, and Robert W. Vishny. 2013. A Model of Shadow Banking. Journal of Finance 68: 1331-63. [CrossRef]

Georgieva, Kristalina. 2020. A Joint Response for Latin America and the Caribbean to Counter the COVID-19 Crisis. Available online: https://www.imf.org/en/News/Articles/2020/06/24/sp062420-a-joint-response-forlatin-america-and-the-caribbean-to-counter-the-covid-19-crisis (accessed on 22 August 2020).

Gertler, Mark, Nobuhiro Kiyotaki, and Albert Queralto. 2012. Financial crises, bank risk exposure and government financial policy. Journal of Monetary Economics 59: S17-S34. [CrossRef]

Goldstein, Morris, Carmen M. Reinhart, and Graciela L. Kaminsky. 2000. Assessing Financial Vulnerability, an Early Warning System for Emerging Markets: Introduction. Available online: http://econpapers.repec. org/paper/pramprapa/13629.htm (accessed on 27 December 2017).

Hancock, Diana, and James A. Wilcox. 1994. Bank capital and the credit crunch: The roles of risk-weighted and unweighted capital regulations. Real Estate Economics 22: 59-94. [CrossRef]

Hughes, Joseph, and Loretta Mester. 1998. Bank capitalization and cost: Evidence of scale economies in risk management and signalling. The Review of Economics and Statistics 80: 314-25. [CrossRef] 
Huljak, Ivan, Martin Reiner, and Moccero Diego. 2019. The Cost-Efficiency and Productivity Growth of Euro Area Banks. August ECB Working Paper No. 2305. Available online: https://ssrn.com/abstract=3430356 (accessed on 15 January 2020).

IMF. 2015. World Economic Outlook. Uneven Growth. Short and Long-Term Factors. International Monetary Fund (IMF). Word Economic and Financial Surveys. Available online: https://www.imf.org/external/pubs/ft/ weo/2015/01/ (accessed on 22 August 2020).

Jensen, Michael C., and William H. Meckling. 1976. Theory of the firm: Managerial behaviour, agency costs and ownership structure. Journal of Financial Economics 3: 305-60. [CrossRef]

Kaminsky, Graciela L., and Carmen M. Reinhart. 1999. The twin crises: The causes of banking and balance-of-payments problems. The American Economic Review 89: 473-500. [CrossRef]

Kane, Edward. 2016. A theory of how and why Central-bank culture supports predatory risk taking at megabanks. International Atlantic Economic Society 44: 51-71. [CrossRef]

Kauko, Karlo. 2012. External deficits and non-performing loans in the recent financial crisis. Economic Letters 115: 2. [CrossRef]

Kleinov, Jacob, Tobias Nell, Silvia Rogler, and Andreas Horsch. 2014. The Value of Being Systemically Important: Event Study on Regulatory Announcement for Banks. Applied Financial Economics 24: 1585-604. [CrossRef]

Köhler, Matthias. 2012. Which Banks are More Risky? The Impact of Loan Growth and Business Model on Bank Risk-Taking. Frankfurt: Deutsche Bundesbank.

Laeven, Luc, and Ross Levine. 2009. Bank governance, regulation and risk taking. Journal of Financial Economics 93: 259-75. [CrossRef]

Laeven, Luc, and Fabián Valencia. 2012. Systemic banking crises database: An update. IMF Working Papers 12: 1. [CrossRef]

Laeven, Luc, Ratnovski Lev, and Tong Hui. 2016. Bank size, capital, and systemic risk: Some international evidence. Journal of Banking \& Finance 69: S25-S34.

Lamas, Matías, and Javier Mencía. 2019. What drives sovereign debt portfolios of banks in a crisis context? Frankfurt am Main, Germany: European Systemic Risk Board. [CrossRef]

Lang, Jan, and Marco Forletta. 2019. Bank capital-at-risk: Measuring the impact of cyclical systemic risk on future bank losses. ECB Working Paper Series. Forthcoming.

Lang, Michael, and Paul G. Schmidt. 2016. The early warnings of banking crises: Interaction of broad liquidity and demand deposits. Journal of International Money and Finance 61: 1-29. [CrossRef]

Lang, Jan, Toumas Peltonen, and Peter Sarlin. 2018. A Framework for Early Warning Modelling with an Application to Banks. European Central Bank (ECB) Working Paper Series 2182: 1-43.

Lapteacru, Ion. 2017. The Z-Score is Dead, Long Live the Z-Score! A New Way to Measure Bank Risk. May 5. Available online: https://ssrn.com/abstract=2963525 (accessed on 10 September 2018). [CrossRef]

Lee, C., and M. Hsieh. 2013. The impact of bank capital on profitability and risk in Asian banking. Journal of International Money and Finance 32: 251-81. [CrossRef]

Liu, Hong, Philip Molyneux, and John Wilson. 2013. Competition, and stability in European banking: A regional analysis. The Manchester School 81: 176-201. [CrossRef]

López, Jose A. 1999. Using CAMELS Ratings to Monitor Bank Conditions. Federal Reserve Bank of San Francisco. June 11. Available online: www.frbsf.org/economic-research/publications/economic-letter/1999/june/usingcamels-ratings-to-monitor-bank-conditions/ (accessed on 7 March 2019).

Lund-Jensen, Kasper. 2012. Monitoring Systemic Risk Based on Dynamic Thresholds. Available online: http://www.econis.eu/PPNSET?PPN=726101990 (accessed on 12 March 2018).

Macchiarelli, Corrado. 2018. Post-Crisis Excess Liquidity and Bank Lending. Brussels: European Parliament.

Mäkinen, Mikko, and Laura Solanko. 2017. Determinants of Bank Closures: Do Changes of CAMEL Variables Matter? Available online: https:/helda.helsinki.fi/bof/handle/123456789/14948 (accessed on 21 December 2018).

Martynova, Natalya. 2015. Bank Profitability and Risk-Taking. (No. 15). Washinton, DC: International Monetary Fund. [CrossRef]

Maudos, Joaquin. 2017. Income structure, profitability, and risk in the European banking sector: The impact of the crisis. Research in International Business and Finance 39: 85-101. [CrossRef]

Maudos, Joaquin, and Juan Fernández de Guevara. 2004. Factors explaining the interest margin in the banking sectors of the european union. Journal of Banking $\mathcal{E}$ Finance 28: 2259-81. 
Maurin, Laurent, and Mervi Toivanen. 2012. Risk, capital buffer and bank lending: A granular approach to the adjustment of euro area banks, No 1499. Working Paper Series, European Central Bank 1499: 1-28.

Wolfe, Simon, Mercieca Steve, and Schaeck Klaus. 2007. Small European Banks: Benefits from Diversification? July 2006. Available online: https://ssrn.com/abstract=949053 (accessed on 7 September 2020). [CrossRef]

Miller, Geoffrey P. 1998. On the Obsolescence of Commercial Banking. Journal of Institutional and Theoretical Economics (JITE) 154: 78-85.

Nguyen, Quang T. T., Son T. B. Nguyen, and Quang V. Nguyen. 2019. Can higher capital discipline bank risk: Evidence from a meta-analysis. Journal of Risk and Financial Management 12: 134. [CrossRef]

De Nicolo, Gianni, Patrick Honohan, and Alain Ize. 2003. Dollarization of the Banking System, Good or Bad. Washinton, DC: International Monetary Fund.

Nyman, Rickard, Sujit Kapadia, David Tuckett, David Gregory, Paul Ormerod, and Robert Smith. 2018. News and Narratives in Financial Systems: Exploring Big Data for Systemic Risk. Bank of England Staff Working Paper No. 704. London: Bank of England.

Obstfeld, Maurice. 2012. Does the Current Account Still Matter? American Economic Review 102: 1-23. [CrossRef]

Oet, Mikhail V., and Stephen J. Ong. 2011. SAFE: An Early Warning System for Systemic Banking Risk. Available online: https://www.openaire.eu/search/publication?articleId=od___ 645:: 6472a15e536bfe669833cc6921b624e9 (accessed on 3 March 2019).

Pellegrini, Carlo, Laura Pellegrini, and Emiliano Sironi. 2019. Explaining Systemic Risk in Latin American Banking Industry over 2002-2015, Asia-Pacific Contemporary Finance and Development (International Symposia in Economic Theory and Econometrics, Vol. 26). Bingley: Emerald Publishing Limited, pp. 287-309.

Petria, Nicolae, Bodgan Capraru, and Iulian Ihnatov. 2015. Determinants of banks' profitability: Evidence from EU 27 banking systems. Procedia Economics and Finance 20: 518-24. [CrossRef]

Petropoulos, Anastasios, Vasilis Siakoulis, Evangelos Stavroulakis, and Nikolaos E. Vlachogiannakis. 2017. Predicting Bank Insolvencies Using Machine Learning Techniques. EBA, European Banking Authority. April. Available online: eba.europa.eu/documents/10180/1813140/Session+2+-+Predicting+bank+insolvencies+ using+machine+learning+techniques.pdf (accessed on 2 September 2020).

Ravi, Kumar P., and Vadlamani Ravi. 2007. Bankruptcy prediction in banks and firms via statistical and intelligent techniques-A review. European Journal of Operational Research 180: 1-28. [CrossRef]

Reinhart, Carmen M., and Kenneth S. Rogoff. 2013. Banking crises. Journal of Banking E Finance 37: 4557-73.

Roengpitya, Rungporn, Nikola Tarashev, and Kostas Tsatsaronis. 2014. Bank business models. BIS Quarterly Review 2014: 55-65.

Rojas-Suarez, Liliana. 2001. Rating Banks in Emerging Markets: What Credit Rating Agencies Should Learn from Financial Indicators. Washinton, DC: Institute for International Economics (IIE).

Rojas-Suárez, Liliana, and Steven R. Weisbrod. 1996. Banking Crises in Latinamerica: Experience and Issues. (No. 321). Washinton, DC: Inter-American Development Bank (IDB).

Rono, Jonathan, and Assetou Traore. 2018. Banks and Sovereign Risk. A Granular View. Washinton, DC: Seminar for Senior Bank Supervisors from Emerging Economies, October 25.

Schich, Sebastian, and Kim Byoung-Hwan. 2010. Systemic Financial Crises: How to fund Resolution. OCDE Journal: Financial Market Trends 2010: 1-34. [CrossRef]

Schliephake, Eva. 2016. Capital regulation and competition as a moderator for banking stability. Journal of Money, Credit and Banking 48: 1787-814. [CrossRef]

Sheng, Andrew. 1996. Bank Restructuring Lessons from the 1980s. Washinton, DC: The World Bank, p. 15384. Available online: http://documents1.worldbank.org/curated/en/533291468766518413/pdf/multi-page.pdf (accessed on 14 March 2018).

Sherbo, Andrew J., and Andrew J. Smith. 2013. The Altman Z-score bankruptcy model at age 45: Standing the test of time? American Bankruptcy Institute Journal 32: 40.

Stackhouse, Julie. 2018. "CAMELS Ratings: Liquidity." St. Louis Fed, Federal Reserve Bank of St. Louis, 19 December 2018. Available online: www.stlouisfed.org/on-the-economy/2018/december/camels-ratingsliquidity (accessed on 12 March 2019).

Stiroh, K. J., and A. Rumble. 2006. The dark side of diversification. Journal of Banking E Finance 30: $2131-61$.

Uhde, Andre, and Ulrich Heimeshoff. 2009. Consolidation in banking and financial stability in Europe. Journal of Banking E Finance 33: 1299-311. 
Valencia, Fabian, and Luc Laeven. 2008. Systemic banking crises: A new database. IMF Working Papers 8: 1. [CrossRef]

Van Greuning, Hennie, and Bratanovic Sonja. 2009. Analyzing Banking Risk, 3rd ed. Washinton, DC: The World Bank. [CrossRef]

Windmeijer, Frank. 2005. A finite sample correction for the variance of linear efficient two-step GMM estimators. Journal of Econometrics 126: 25-51. [CrossRef]

Xu, TengTeng, Hu Kun, and Udaibir Das. 2019. Bank Profitability and Financial Stability IMF 2019. Available online: https://www.imf.org/ \{\}/media/Files/Publications/WP/2019/wp1905.ashx (accessed on 1 March 2020).

Yi, Wang. 2012. Z-score model on financial crisis early-warning of listed real estate companies in china: A financial engineering perspective. Systems Engineering Procedia 3: 153-57. [CrossRef]

C 2020 by the authors. Licensee MDPI, Basel, Switzerland. This article is an open access article distributed under the terms and conditions of the Creative Commons Attribution (CC BY) license (http://creativecommons.org/licenses/by/4.0/). 